\title{
Chemical and microbiological oxidation of (-)-cis-carane-4-one leading to chiral compounds and evaluation of their antifeedant activity
}

\author{
Ewelina Wincza ${ }^{\mathrm{a}}$ and Stanisław Lochyński ${ }^{\mathrm{a}, \mathrm{b}^{*}}$ \\ ${ }^{a}$ Department of Bioorganic Chemistry, Wrocław University of Technology, Wybrzeże \\ Wyspiańskiego 27, 50 -370, Wrocław, Poland \\ ${ }^{b}$ Institute of Cosmetology, Wrocław College of Physiotherapy, Kościuszki 4, 50-038, Wrocław, \\ Poland \\ E-mail: stanislaw.lochynski@pwr.wroc.pl
}

Dedicated to Prof. Pawel Kafarski to honor the achievements within his career

\begin{abstract}
Starting from (+)-3-carene 1, naturally occurring bicyclic, monoterpene hydrocarbon, (-)-ciscarane-4-one $\mathbf{3}$ was obtained as a result of the two-step synthesis. Our investigations were focused on the optimization of chemical Baeyer-Villiger reaction of $\mathbf{3}$ leading to $\varepsilon$-lactones. A mixture of terpenoid lactones $\mathbf{4 a}, \mathbf{4 b}$ was obtained and next separated using column chromatography. The pure compounds were subjected to the evaluation of antifeedant activity towards three species of storage insects. Fusarium culmorum, Fusarium oxysporum and Aspergillus niger were chosen among six fungal strains to perform microbiological BaeyerVilliger oxidation. As a result, three derivatives were isolated and characterized by spectroscopic methods.
\end{abstract}

Keywords: Terpenoid lactones, Baeyer-Villiger reaction, biotransformation, antifeedants

\section{Introduction}

Terpenoid lactones belong to a large class of compounds possessing various biological activities (fungicidal, germicidal, antitumor, antimicrobial, insecticidal and odoriferous). We are interested in studying the structure-activity relationship for sesqui- and monoterpenoid lactones with insect feeding deterrent activity. ${ }^{1,2}$ While $\gamma$ - and $\delta$-lactones are very widespread in the nature and well characterized in the literature, $\varepsilon$-lactones are relatively rare and also exhibit useful biological properties. 
(-)-cis-Carane-4-one 3, obtained from (+)-3-carene in a two-step reaction was subjected to the chemical and microbiological process of Baeyer-Villiger oxidation. The Baeyer-Villiger (BV) oxidation of ketones, described more than a century ago, is of great interest in organic chemistry. In spite of numerous efforts leading to increasing enantiopurity, asymmetric BV oxidation using conventional chemistry still has not been satisfactorily achieved. ${ }^{3}$ Conversely, the microbiological methods has been known to be an efficient way for achieving such reactions in a highly enantioselective manner. ${ }^{4}$

Herein, we present an effective and convenient synthetic method of terpenoid lactones using Baeyer-Villiger reaction. Since the first report concerning oxidation of cyclic ketone to lactone using the peroxycarboxylic acid in $1899,{ }^{5}$ there were several methods published in the literature over few decades. Many methods used trifluoroperacteic acid, $m$-chloroperbenzoic acid with trifluoroacteic acid, 1,1,1,3,3,3-hexafluoro-2-propanol with hydrogen peroxide, bis(trimethylsilyl) peroxide with stannic chloride, and a combination of oxygen, benzaldehyde, magnesium oxide and copper. ${ }^{6}$

Development of biocatalytic methods is a continuously growing area of chemistry, due to the fact that biocatalysts are selective, easy-to-handle, and environmentally friendly. A wide range of reactions are catalyzed by microorganisms. Fungi can be considered as a promising source of new biocatalysts, mainly for chiral reactions. ${ }^{7}$ Chemo-, regio-, and stereoselective processes are very important in the synthesis of many chemicals with various biological activity. ${ }^{8}$ Biological Baeyer-Villiger oxidations are catalyzed by enzymes belonging to NADPH or NADH dependent flavoproteines called BV monooxygenases.

Our studies were focused on the optimization of chemical BV oxidation process of ketone $\mathbf{3}$ that is obtained from the natural monoterpenoid hydrocarbon $\mathbf{1}$, and also on the evaluation of usefulness of Fusarium culmorum, Fusarium oxysporum and Aspergillus niger for obtaining \&lactones from the mentioned substrate. Next, the biological properties of the obtained lactones were determined. Herein, we present for the first time the antifeedant activity of the discussed compounds and the results of microbiological transformations of bicyclic ketone.

\section{Results and Discussion}

The key compound, (-)-cis-carane-4-one 3 was readily obtained from (+)-3-carene by a two step stereocontroled borohydration-oxidation followed by the Brown-Garg oxidation of crystalline (-)-cis-carane-trans-4-ol 2. ${ }^{9} \mathrm{BH}_{3}$ was generated in situ, in the reaction of lithium aluminium hydride $(\mathrm{LAH})$ with $\mathrm{BF}_{3}$. In the next step, the carane derivative was oxidized with hydrogen peroxide under alkaline conditions aiming to obtain (-)-cis-carane-trans-4-ol. Reaction of compound 3 with $m$-chloroperbenzoic acid provided lactones $\mathbf{4 a}$ and $\mathbf{4 b}$ with $90 \%$ yield (Scheme 1). In the Baeyer-Villiger rearrangement the oxidative cleavage of a carbon-carbon bond adjacent to a carbonyl takes place, which converts the cyclic ketones into lactones. The oxidations were performed under acidic conditions. We have examined several procedures of Baeyer-Villiger reaction. ${ }^{10}$ This investigation included the variables, such as oxidative reagent, 
reaction temperature and time, addition of anhydrous $\mathrm{MgSO}_{4}$ aiming to provide water-free conditions. The desirable products were obtained in each run of the investigated methods. However, in case of 1-8 runs, it turned out low yield, very long time of the carried attempts and lots of side products that made impossible to isolate the final compounds. Moreover, we have observed that the addition of 10.0 equivalents of anhydrous $\mathrm{MgSO}_{4}$ and $\mathrm{NaHCO}_{3}$ reduced reaction time and slightly improved efficiency. The results are presented in Table 1. It turned out that the most effective and useful was the experiment with $m$-CPBA under solvent-free conditions, in room temperature. For economy and pollution reasons, the solvent-free methods are of great interest in order to modernize classical procedures making them more clean, safe and easy to perform. Reactions on solid mineral supports, reactions without any solvent or catalyst, and solid-liquid phase transfer catalysis can be thus employed with noticeable increases in reactivity and selectivity. ${ }^{11}$
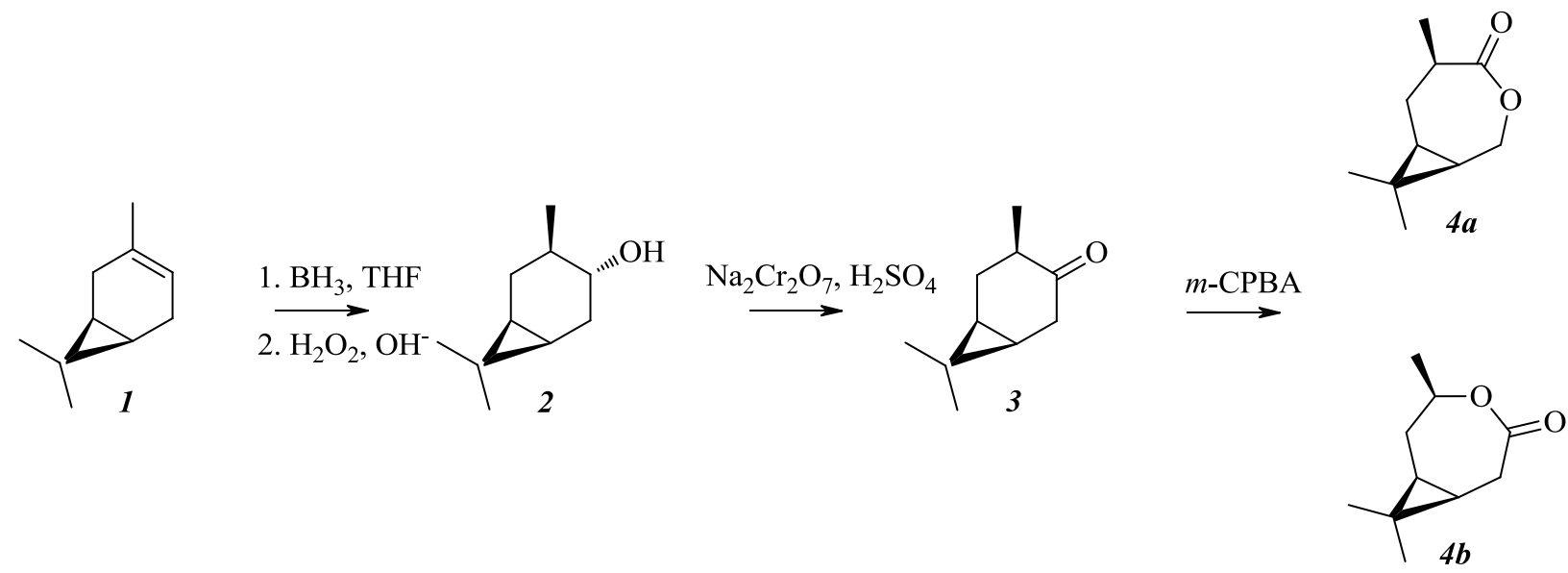

Scheme 1

Table 1. Conditions and results of Baeyer-Villiger oxidations

\begin{tabular}{cccccc}
\hline Run & Oxidative reagent & Solvent & Temperature, ${ }^{\circ} \mathrm{C}$ & Yield, \% & Time, $\mathrm{h}$ \\
\hline $\mathbf{1}$ & $\mathrm{H}_{2} \mathrm{O}_{2}, \mathrm{HCOOH},(1: 1)$ & $\mathrm{CH}_{2} \mathrm{Cl}_{2}$ & 25 & 10 & 168 \\
$\mathbf{2}$ & $\mathrm{H}_{2} \mathrm{O}_{2}, \mathrm{TFA},(1: 1)$ & $\mathrm{CH}_{2} \mathrm{Cl}_{2}$ & 25 & 15 & 168 \\
$\mathbf{3}$ & $m$-CPBA, TFA, (1:1) & $\mathrm{CH}_{2} \mathrm{Cl}_{2}$ & 0 & 15 & 168 \\
$\mathbf{4}$ & $m$-CPBA 2 eq. & $\mathrm{CH}_{2} \mathrm{Cl}_{2}$ & 25 & 55 & 168 \\
$\mathbf{5}$ & $m$-CPBA* 2 eq. & $\mathrm{CH}_{2} \mathrm{Cl}_{2}$ & 25 & 60 & 120 \\
$\mathbf{6}$ & $m$-CPBA 3 eq. & $\mathrm{CH}_{3} \mathrm{Cl}_{2}$ & 40 & 65 & 120 \\
$\mathbf{7}$ & $m$-CPBA 4 eq. & $\mathrm{CH}_{2} \mathrm{Cl}_{2}$ & 40 & 54 & 110 \\
$\mathbf{8}$ & $m$-CPBA** 4 eq. & $\mathrm{CH}_{2} \mathrm{Cl}_{2}$ & 40 & 60 & 92 \\
$\mathbf{9}$ & $m$-CPBA 2.6 eq. & without & 25 & 90 & 0.5 \\
\hline
\end{tabular}

*with addition of anhydrous $\mathrm{MgSO}_{4}$ (10.0 equiv).

*** with addition of $\mathrm{NaHCO}_{3}(10.0$ equiv). 
In the literature, there are examples of the BV oxidation of the cyclic ketones leading to $\varepsilon$ lactones using Fusarium sp. ${ }^{7}$ Relying on this data, after the screening-scale experiments using six fungal strains, we decided to apply Fusarium oxysporum, Fusarium culmorum and Aspergillus niger. The following metabolites were identified after biotransformations of $\mathbf{3}$, by $A$. niger: (-)-cis-caran-trans-4-ol 2, (-)-10-hydroxy-cis-caran-4-one 5 and (-)-3,10-epoxy-ciscaran-4-one 6, by F. oxysporum and F. culmorum: (-)-cis-caran-trans-4-ol 2, (-)-10-hydroxycis-caran-4-one 5 (Table 2). In contrary to our expectations, it turned out, that the used fungi species did not possess the ability to perform BV oxidation of (-)-cis-carane-4-one 3 . In the reaction mixtures, products with lactone moiety were not observed. The structure and stereochemistry of obtained compounds was determined by GC-MS, ${ }^{1} \mathrm{H}$ NMR, ${ }^{13} \mathrm{C}$ NMR spectra and HMQC correlation.

Table 2. Result of biotransformations

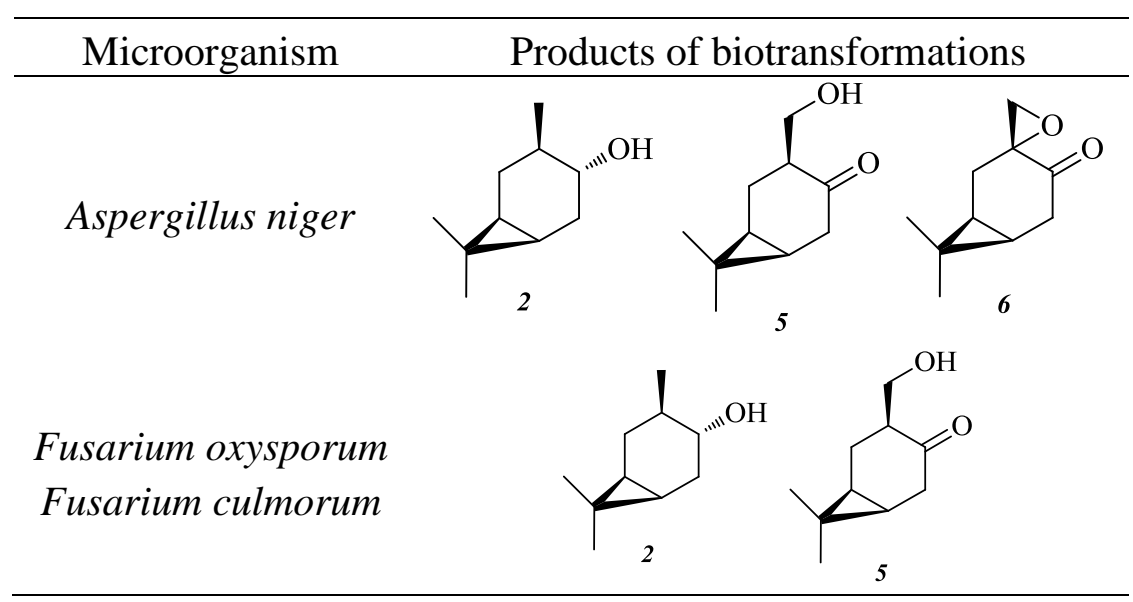

In case of $A$. niger, the highest rate of conversion was observed. After two days of process, the substrate was not detected in the reaction mixture. $F$. oxysporum and $F$. culmorum transformed ketone 3 slower, generally it lasted about seven days. The yields of isolated compounds were low because of possible consumption by microorganisms as well as by losses during column chromatography.

To summarize, only the chemical method of BV oxidation provides the desired products. However, as the result of microbiological transformations we isolated unexpected but very interesting hydroxyketone 5 and epoxyketone 6. In all cases we observed the formation of alcohol 2 as the product of reduction of carbonyl group. The applied strains of $A$. niger possess the redox activity and they formed alcohols $\mathbf{2 , 5}$ and epoxyketone $\mathbf{6}$ from the starting ketone.

The obtained lactones were tested for antifeedant activity against three storage pest insects: the grain weevil (Sitophilus granarius, adults), the confused flour beetle (Trogoderma granarium, larvae) and the khapra beetle (Tribolium confusum, larvae and adults). The compounds tested showed low activity towards Tribolium confusum and Trogoderma granarium (the total coefficient of deterrence from -1.9 to +57.5 ) and moderate activity against Sitophilus 
granarius (the total coefficient of deterrence 76.4 and 93.5). For comparison, the total coefficient for azadirachtin determined in the same manner, as mentioned above, reaches values almost 200. The total coefficient between 150 and 200 characterizes very active antifeedants. Coefficients and theirs values for the analyzed compounds are presented in Table 3 .

Table 3. The coefficients of deterrence

\begin{tabular}{cccccc}
\hline \multirow{2}{*}{ Compound } & Coefficient & \multicolumn{2}{c}{ Tribolium confusum } & $\begin{array}{c}\text { Trogoderma } \\
\text { granarium }\end{array}$ & $\begin{array}{c}\text { Sitophilus } \\
\text { granarius }\end{array}$ \\
\cline { 3 - 6 } & & adults & larvae & larvae & adults \\
\hline \multirow{3}{*}{ 4a } & relative & 64.7 & 19.9 & -24.2 & 87.2 \\
& absolute & -7.1 & 16.6 & 22.3 & 6.3 \\
& total & $\mathbf{5 7 . 5}$ & $\mathbf{3 6 . 5}$ & $-\mathbf{1 . 9}$ & $\mathbf{9 3 . 5}$ \\
& relative & -2.4 & 25.0 & -32.4 & 74.1 \\
& absolute & 5.1 & 10.3 & 33.2 & 2.3 \\
& total & $\mathbf{2 . 7}$ & $\mathbf{3 5 . 3}$ & $\mathbf{0 . 8}$ & $\mathbf{7 6 . 4}$ \\
\hline
\end{tabular}

\section{Experimental Section}

General. (+)-3-Carene was purchased from Acros Organics $\left([\alpha]_{D}{ }^{20}=+15.3\right.$ (neat), $\mathrm{n}_{\mathrm{D}}{ }^{20}=$ $1.4697, \mathrm{~d}=0.864 \mathrm{~g} / \mathrm{cm}^{3}, \mathrm{bp}=170-171^{\circ} \mathrm{C}$, ee $=100 \%$ ). Fusarium oxysporum, Fusarium culmorum and Aspergillus niger were from Department of Bioorganic Chemistry, Wroclaw University of Technology, and were previously isolated in our laboratory and identified by DSMZ, Braunschweig, Germany. All materials were purchased from commercial suppliers: Sigma, Aldrich, Fluka, POCh, Acros Organics.

The courses of all reactions were checked by thin-layer chromatography (TLC). TLC was carried out on percoated TLC plates with silica gel 60F-254 with visualization by irradiation with a short-wavelength UV light. Chromatograms were developed with a mixture of $n$-hexane and ethyl acetate, diethyl ether applied in various ratios and detected with $20 \%$ methanolic $\mathrm{H}_{2} \mathrm{SO}_{4}$ with $0.1 \%$ anisaldehyde. For the column chromatography the Kieselgel Merck 60 silica gel (0.040-0.063 mm) was used. GC-MS analysis was performed on Waters GCT Premier with a capillary column HP-5 30m x $0.250 \mu \mathrm{m} .{ }^{1} \mathrm{H}$ and ${ }^{13} \mathrm{C}$ NMR spectra were recorded in $\mathrm{CDCl}_{3}$ with TMS as an internal standard on a Bruker Avance ${ }^{\mathrm{TM}}$ DRX 300 or Bruker Avance ${ }^{\mathrm{TM}}$ DRX 600 instrument. Chemical shifts $(\delta)$ are reported in ppm, coupling constants $(J)$ are given in Hz. The types of signal were noted: singlet-s, doublet-d, triplet-t, multiplet-m, etc. IR spectra were recorded with Perkin-Elmer 621 spectrometer using liquid films and are given in wave numbers $\left(\mathrm{cm}^{-1}\right)$. Melting point was determined on a Boetius apparatus. Optical rotation measurements were obtained on the Polar 31 (Optical Activity) LTD polarimeter as a solution of chloroform. The deterrent activity of obtained compounds was evaluated by Professor Jan Nawrot from the Institute of Plant Protection in Poznan. 


\section{Procedure for Baeyer-Villiger oxidation}

To a roundbottom flask was added $1.00 \mathrm{~g}(6.58 \mathrm{mmol})$ of $(-)$-cis-carane-4-on $\mathbf{3}$ and $2.30 \mathrm{~g}$ (13.35 mmol) of $m$-chloroperbenzoic acid. A reflux condenser was immediately attached to the flask. After about $1 \mathrm{~min}$, the reaction mixture becomes warm, and then was stirred with spatula once every $5 \mathrm{~min}$ for $30 \mathrm{~min}$. When the reaction was completed, the mixture was treated with $20 \%$ aqueous solution of $\mathrm{Na}_{2} \mathrm{~S}_{2} \mathrm{O}_{3}$ to decompose the excess peroxy acid. Next, the reaction mixture was diluted with diethyl ether and washed with aqueous solution of $\mathrm{NaHCO}_{3}$ and water. The organic fraction was collected, dried with anhydrous $\mathrm{MgSO}_{4}$ and concentrated in vacuum. Crude products were separated and purified by column chromatography (silica gel, hexane/diethyl ether, 10:1) to give pure lactones $\mathbf{4 a}$ as a yellow oil and $\mathbf{4 b}$ as white crystals.

(+)-(1R,5R,7S)-5,8,8-Trimethyl-3-oxabicyclo[5.1.0]octan-4-one (4a). Yield: 0.405 g, 2.41 mmol, $45 \%,[\alpha]_{\mathrm{D}}{ }^{23}=+73\left(1.85 \mathrm{CHCl}_{3}\right), \mathrm{n}_{\mathrm{D}}{ }^{22}=1.4774$, GC-MS: $m / z=168.1082\left(\mathrm{M}^{+}\right)$, IR (film,

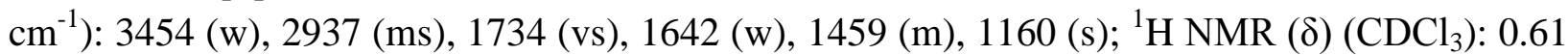
and $0.70(\mathrm{~m}, 2 \mathrm{H}$ at $\mathrm{C}-1$ and $\mathrm{C}-7), 1.03$ and $1.07(2 \mathrm{~s}, 6 \mathrm{H}$ at $\mathrm{C}-9$ and $\mathrm{C}-10), 1.10(\mathrm{~d}, J=7.1 \mathrm{~Hz}, 3 \mathrm{H}$ at C-11), $1.61(\mathrm{td}, J=11.2,4.7 \mathrm{~Hz}, 1 \mathrm{H}$ at C-6), 1.85 (dd, $J=15.5,9.6 \mathrm{~Hz}, 1 \mathrm{H}$ at C-6), $2.85(\mathrm{~m}$, $1 \mathrm{H}$ at C-5), $4.05\left(\mathrm{dd}, J=14.2,5.1 \mathrm{~Hz}, 1 \mathrm{H}\right.$ at C-2), $4.15(\mathrm{dd}, J=13.9,4.9 \mathrm{~Hz}, 1 \mathrm{H}$ at $\mathrm{C}-2) ;{ }^{13} \mathrm{C}$ NMR $(\delta)\left(\mathrm{CDCl}_{3}\right): 16.75$ and 17.78 (C-9 and C-10), $18.87(\mathrm{C}-8), 19.50(\mathrm{C}-1), 21.76(\mathrm{C}-7), 23$. 53 (C-11), 31.57 (C-6), 34.89 (C-5), 69.56 (C-2), 174.54 (C-4).

(+)-(1R,5R,7S)-5,8,8-Trimethyl-4-oxabicyclo[5.1.0]octan-3-one (4b). Yield: 0.495 g, 2.94 mol, $55 \%,[\alpha]_{\mathrm{D}}^{23}=+72\left(1.85 \mathrm{CHCl}_{3}\right), \mathrm{m}_{\mathrm{p}}=40.2^{\circ} \mathrm{C}, \mathrm{GC}-\mathrm{MS}: \mathrm{m} / z=168.1106\left(\mathrm{M}^{+}\right)$, IR $\left(\mathrm{film}, \mathrm{cm}^{-1}\right)$ :

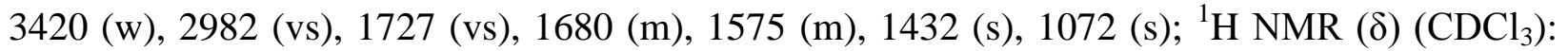
0.63-0.70 (m, $1 \mathrm{H}$ at C-1), 0.78-0.87 (m, $1 \mathrm{H}$ at C-7), 0.96 and 0.99 (2s, 6H at C-9 and C-10), $1.24(\mathrm{~d}, J=6.4 \mathrm{~Hz}, 3 \mathrm{H}$ at C-11), $1.72(\mathrm{td}, J=10.7,5.1 \mathrm{~Hz}, 1 \mathrm{H}$ at C-6), $2.05(\mathrm{dd}, J=16.3,10.0$ $\mathrm{Hz}, 1 \mathrm{H}$ at C-6), 2.90 (dd, $J=15.6,4.2 \mathrm{~Hz}, 1 \mathrm{H}$ at C-2), 3.10 (dd, $J=15.6,4.9 \mathrm{~Hz}, 1 \mathrm{H}$ at C-2), 4.51-4.61 (m, $1 \mathrm{H}$ at C-5); ${ }^{13} \mathrm{C}$ NMR $(\delta)\left(\mathrm{CDCl}_{3}\right): 14.94$ and $29.14(\mathrm{C}-9$ and $\mathrm{C}-10), 18.81(\mathrm{C}-8)$, 20.82 (C-1), 22.13 (C-11 and C-7), 30.71 (C-6), 33.14 (C-2), 76.98 (C-5), 173.19 (C-3).

\section{Procedure for biotransformation}

Microorganisms were cultivated on rotatory platform $(160 \mathrm{rpm})$ at $28^{\circ} \mathrm{C}$ for $24-48 \mathrm{~h}$ in a $250 \mathrm{ml}$ Erlenmeyer flask containing $150 \mathrm{ml}$ sterile $\alpha$-medium (consisting of $20.0 \mathrm{~g}$ glucose, $5.0 \mathrm{~g}$ yeast extract, $5.0 \mathrm{~g}$ peptone, $5.0 \mathrm{~g} \mathrm{NaCl}, 5.0 \mathrm{~g} \mathrm{Na}_{2} \mathrm{HPO}_{4}$ per litre distilled water adjusted to $\mathrm{pH} \mathrm{7.0).}$ After full growth of microorganisms $75 \mathrm{mg}$ of ketone 3 was added and culture was incubated for 7 days under the same conditions. Products of biotransformations were screened by liquid-liquid extraction of the culture broth $(3 \mathrm{ml})$ which was extracted exhaustively by ethyl acetate, concentrated and evaluated by TLC and GC/MS analysis. Biotransformation controls consisted of fermentation blanks in which the microorganisms were grown under identical conditions but without the addition of substrate. After the incubation period, controls were also harvested and analyzed by TLC. Routine analyses were performed on pre-coated silicagel G-25 UV 254 plates. The concentrated ethyl acetate extracts were applied on silica gel chromatography column to 
give pure metabolites as pale yellow oils. Hexane:ethyl acetate in different ratio was used as an eluent for purification.

(-)-cis-Carane-trans-4-ol (2). Yield: for A. niger: 28\%, for F. oxysporum: 19\%, for $F$. culmorum: $15 \%,[\alpha]_{\mathrm{D}}{ }^{20}=-63.4(10.0, \mathrm{EtOH}), \mathrm{n}_{\mathrm{D}}{ }^{20}=1.4791$; GC-MS: $m / z=154.1247\left(\mathrm{M}^{+}\right), \mathrm{IR}$ (film, $\mathrm{cm}^{-1}$ ): 3418(vs), 2932(vs), 1704(w), 1456(m), 1376(m), 1048(s), ${ }^{1} \mathrm{H} \mathrm{NMR}\left(\mathrm{CDCl}_{3}, \delta\right.$, ppm): 0.61 (m, $1 \mathrm{H}$ at C-1); $0.69(\mathrm{~m}, 1 \mathrm{H}$ at C-6); $1.04 ; 1.06(2 \mathrm{~s}, 6 \mathrm{H}$ at C-8 and C-9); $1.20(\mathrm{~d}, J=$ $6.4 \mathrm{~Hz}, 3 \mathrm{H}$ at C-10); $1.41(\mathrm{dd}, J=15.1,5.7 \mathrm{~Hz}, 2 \mathrm{H}$ at C-2); $1.76(\mathrm{dd}, J=15.2,9.0 \mathrm{~Hz}, 2 \mathrm{H}$ at C5); 2.30 (m, $1 \mathrm{H}$ at C-3); 3.55 (ddd, $J=7.3,2.8,1.2 \mathrm{~Hz}, 1 \mathrm{H}$ at $\mathrm{C}-4),{ }^{13} \mathrm{C} \mathrm{NMR}\left(\mathrm{CDCl}_{3}, \delta, \mathrm{ppm}\right)$ : 15.14 (C-8 and C-9), 17.52 (C-1), 17.56 (C-6), 18.09 (C-7), 25.07 (C-10), 25.61 (C-2), 28.07 (C5), 28.81 (C-8 and C-9), 24.09 (C-3), 71.61 (C-4)

(-)-10-Hydroxy-cis-carane-4-one (5). Yield: for A. niger: $23 \%$, for $F$. oxysporum: $15 \%$, for $F$. culmorum: $19 \%,[\alpha]_{\mathrm{D}}{ }^{24}=-112.0\left(1.0 \mathrm{CHCl}_{3}\right)$, GC-MS: $m / z=168.1179\left(\mathrm{M}^{+}\right), \mathrm{IR}\left(\mathrm{film}, \mathrm{cm}^{-1}\right)$ : 3441(m), 2932(m), 1709(vs), 1456(w), 1017(m), ${ }^{1} \mathrm{H}$ NMR $\left(\mathrm{CDCl}_{3}, \delta, \mathrm{ppm}\right): 0.96 ; 0.98(2 \mathrm{~s}, 6 \mathrm{H}$ at C-8 and C-9); 1.13-1.19 (m, 2H at C-1 and C-6); 1.22 (t, $J=4.8 \mathrm{~Hz}, 2 \mathrm{H}$ at C-2); 2.32 (dd, $J=$ $12.2,4.8 \mathrm{~Hz}, 1 \mathrm{H}$ at C-5); $2.37-2.45(\mathrm{~m}, 1 \mathrm{H}$ at C-3); $2.58(\mathrm{dd}, J=12.3,5.8 \mathrm{~Hz}, 1 \mathrm{H}$ at C-5); 3.37 $\left(\mathrm{d}, J=8.3 \mathrm{~Hz}, 2 \mathrm{H}\right.$ at C-10), ${ }^{13} \mathrm{C} \mathrm{NMR}\left(\mathrm{CDCl}_{3}, \delta\right.$, ppm): 10.58 (C-8 and C-9), 14.08 (C-8 and C9), 17.22 (C-1), 19.83 (C-6), 26.23 (C-7), 29.15 (C-2), 36.42 (C-5), 41.89 (C-3), 72.18 (C-10), $215.86(\mathrm{C}-4)$

(-)-3,10-Epoxy-cis-carane-4-one (6). Yield: for $F$. oxysporum: $24 \%$, for $F$. culmorum: $27 \%$, $[\alpha]_{\mathrm{D}}{ }^{24}=-54.6\left(1.0 \mathrm{CHCl}_{3}\right)$, GC-MS: $\mathrm{m} / z=166.1218\left(\mathrm{M}^{+}\right)$, IR (film, $\left.\mathrm{cm}^{-1}\right): 3358(\mathrm{w}), 2936(\mathrm{~m})$, 1700(vs), 1565(w), 1215(m), ${ }^{1} \mathrm{H} \mathrm{NMR}\left(\mathrm{CDCl}_{3}, \delta, \mathrm{ppm}\right): 1.00$ (s, 3H at C-8 and C-9); 1.02-1.09 (m, $1 \mathrm{H}$ at C-1); 1.21 (s, 3H at C-8 and C-9); 1.34 (td, $J=8.9,3.2 \mathrm{~Hz}, 1 \mathrm{H}$ at C-6); 1.59 (dd, $J=$ $15.8,5.8 \mathrm{~Hz}, 1 \mathrm{H}$ at C-2); $2.25(\mathrm{dd}, J=16.9,3.1 \mathrm{~Hz}, 1 \mathrm{H}$ at C-5); $2.36(\mathrm{dd}, J=15.8,9.1 \mathrm{~Hz}, 1 \mathrm{H}$ at $\mathrm{C}-2) ; 2.90(\mathrm{dd}, J=16.9,8.5 \mathrm{~Hz}, 1 \mathrm{H}$ at $\mathrm{C}-5) ; 3.36(\mathrm{~s}, 2 \mathrm{H}$ at $\mathrm{C}-10),{ }^{13} \mathrm{C} \mathrm{NMR}\left(\mathrm{CDCl}_{3}, \delta, \mathrm{ppm}\right)$ : 10.30 (C-8 and C-9), 13.98 (C-1), 20.10 (C-6), 23.37 (C-8 and C-9), 26.39 (C-7), 33.62 (C-5), 34.72 (C-2), 71.93 (C-10), 72.65 (C-3), 213.91 (C-4)

\section{Acknowledgements}

The authors would like to thank the Polish Ministry of Science and Higher Education for supporting this work (Grant No N204 019335) and project "Biotransformations for pharmaceutical and cosmetics industry" No. POIG.01.03.01-00-158/09-00, partly financed by the European Union within the European Regional Development Fund. We wish to express our thanks to Professor Jan Nawrot from the Institute of Plant Protection in Poznań for the evaluation of antifeedant activity.

\section{References}

1. Lochyński, S.; Frąckowiak, B.; Olejniczak, T.; Ciunik, Z.; Wawrzeńczyk, C. Tetrahedron: Asymmetry 2002, 13, 1761. 
2. Frąckowiak, B.; Ochalik, K.; Białońska, A.; Ciunik, Z.; Wawrzeńczyk, C.; Lochyński, S. Tetrahedron: Asymmetry 2006, 17(1), 3352.

3. Watanabe, A.; Uchida, T.; Ito, K.; Katsuki, T. Tetrahedron Lett. 2002, 43, 4481 and references cited therein.

4. (a) Willetts, A. Trends Biotechnol. 1997, 15, 515. (b) Roberts, S. M.; Wan, P. W. H. J. Mol Catal B: Enzym 1998, 4, 111. (c) Alphand, V.; Furstoss, R. Baeyer-Villiger oxidations. In Enzyme Catalysis in Organic Synthesis: a Comprehensive Handbook, Drauz, K.; Waldmann, H., Eds.; VCH: Weinheim, 1995; Vol. 2, pp 745.

5. Baeyer, A.; Villiger, V. Ber. Deut. Chem. Ges. 1989, 32, 3625.

6. (a) Sager, W. F.; Duckworth, A. J. Am. Chem. Soc. 1955, 77, 188. (b) Neumann, K.; Neumann, R. Org. Lett. 2000, 2, 2861. (c) Matsubara, S.; Takai, K.; Nozaki, H. B Chem Soc Jpn 1983, 56, 2029. (d) Yan, Y. Y.; Dong, L. M.; Guo, J. P.; Huang, M. Y., Jiang, Y. Y. J Macromol. Sci. 1997, 34, 1097.

7. Ratuś, B.; Gładkowski, W.; Wawrzeńczyk, C. Enzyme Microb. Technol. 2009, 45, 156.

8. Borges, K. B.; de Souza Borges, W.; Durán-Patrón, R.; Pupo, M. T.; Bonato, P. S.; Collado, I. G. Tetrahedron: Asymmetry 2009, 20, 385.

9. Lochyński, S.; Kułdo, J.; Frąckowiak, B.; Holland, J.; Wójcik, G. Tetrahedron: Asymmetry 2000, 11, 1295.

10. (a) Dhillon, R. S.; Gautman, V. K.; Singh, S.; Singh, J. Indian J. Chem. 1991, 30B, 574. (b) Koch, S. S. C.; Chamberlin, A. R. Synth. Commun. 1989, 19, 829. (c) Lamers, Y. M. A. W.; Rusu, G.; Wijnberg, J. B. P. A.; de Groot, A. T. Tetrahedron 2003, 59, 9361. (d) Esteb, J. J.; Hohman, J. N.; Schlamadinger, D. E.; Wilson, A. M. A. J. Chem. Educ. 2005, 82, 1837.

11. Loupy, A. Modern Solvents in Organic Synthesis; Springer: Berlin / Heidelberg, 1999; pp. 153. 